Turkish Online Journal of Qualitative Inquiry (TOJQI)

Volume 10, Issue 1, January 2019: 26-51

DOI: $10.17569 /$ tojqi.438333

Research Article

\title{
Analysis of Digital Citizenship Subject Contents of Secondary Education Curricula
}

\author{
Uğur Başarmak ${ }^{1}$, Hamza Yakar², Erhan Güneş ${ }^{3}$, Zafer Kuş ${ }^{4}$
}

\begin{abstract}
The aim of this study is to analyze the secondary education curricula in terms of the subdimensions of digital citizenship. Curricula used for secondary education (High School $1^{\text {st }}, 2^{\text {nd }}, 3^{\text {rd }}$ and $4^{\text {th }}$ Grades) in the 2017-2018 academic year were used as data source. The curricula examined in this scope belong to the following courses: Computer Science, English, Geopgraphy, Democracy and Human Rights, Religion and Ethics, Philosophy, French, Visual Arts, Music, Medical Knowledge and Traffic, Revolution History and Atatürkism, History, Turkish Language and Literature and Contemporary Turkish and World History. The study was carried out with qualitative research methods, and data were collected through document review. In the analysis of the data, induction analysis method was used on the basis of "Digital Citizenship Scale for the Young" developed by Kuş, Güneş, Başarmak and Yakar (2017). The present study reveals that the courses having the highest number of references to digital citizenship in the curricula are "computer science" and "democracy and human rights". Although computer science curriculum gives wide coverage to digital skills, the coverage of rights and responsibilities in the digital environment and ethical and critical thinking skills is limited. In the curricula of the other courses, contents related digital citizenship are highly limited.
\end{abstract}

Key words: Citizenship, digital citizenship, secondary education curriculum, content analysis

\footnotetext{
1 Asst.Prof.Dr., Ahi Evran University, Faculty of Education, Department of Computer Education \& Instructional Technology, ugurbasarmak @ gmail.com. https://orcid.0000-0002-2762-1806

${ }^{2}$ Res.Asst., Ahi Evran University, Faculty of Education, Department of Social Sciences and Turkish Education, hmzyakar@gmail.com, https://orcid.org/0000-0002-9334-3525

3 Asst.Prof.Dr., Ahi Evran University, Faculty of Education, Department of Computer Education \& Instructional Technology, guneserhan@gmail.com. https://orcid.org/0000-0002-4268-4645

${ }^{4}$ Assoc.Prof.Dr., Ahi Evran University, Faculty of Education, Department of Social Sciences and Turkish Education, zaferkus@gmail.com, https://orcid.org/0000-0002-4371-8114
}

Received: 28.06.2018 Accepted: 30.01.2019 


\title{
Ortaöğretim Programlarının Dijital Vatandaşlık Konu İçeriklerinin Analizi
}

\begin{abstract}
$\ddot{O} z$
$\mathrm{Bu}$ araştırmanın amacı ortaöğretim programlarının dijital vatandaşlı̆̆ın alt boyutları açısından analiz edilmesidir. Araştırmada 2017-2018 eğitim-öğretim yılında, ortaöğretim düzeyinde (Lise 1, 2, 3, 4 sınıf) uygulanan öğretim programları veri kaynağı olarak kullanılmıştır. Bu kapsamda incelenen ortaöğretim programları: Bilgisayar Bilimi, İngilizce, Coğrafya, Demokrasi ve İnsan Hakları, Din Kültürü ve Ahlak Bilgisi, Felsefe, Fransızca, Görsel Sanatlar, Müzik, Sağlık Bilgisi ve Trafik, T.C. İnkılap Tarihi ve Atatürkçülük, Tarih, Türk Dili ve Edebiyatı, Çağdaş Türk ve Dünya Tarihi dersleridir. Araştırma, nitel araştırma yöntemiyle gerçekleştirilmiş, araştırma verileri doküman incelemesi yoluyla toplanmıştır. Verilerin çözümlenmesinde, Kuş, Güneş, Başarmak ve Yakar (2017) tarafından geliştirilen "Gençlere Yönelik Dijital Vatandaşlık Ölçeği” esas alınarak tümevarım analizi yöntemi kullanılmıştır. Araştırma sonucunda, dijital vatandaşlıkla ilgili en fazla içeriğe "bilgisayar bilimi" ile "demokrasi ve insan hakları” öğretim programında yer verildiği görülmektedir. Bilgisayar bilimi dersi öğretim programında dijital becerilere geniş yer bir şekilde verilmesine ragmen; dijital ortamdaki hak ve sorumluluk, etik ve eleştirel düşünme becerilerine çok az yer verilmiştir. Diğer derslerin öğretim programında ise dijital vatandaşlıkla ilgili oldukça sınırlı içeriğe rastlanılmaktadır.
\end{abstract}

Anahtar Sözcükler: Vatandaşlık, dijital vatandaşlık, ortaöğretim programı, içerik analizi 


\section{Introduction}

The fact that internet becomes more accessible to the masses day by day and thus spreads rapidly makes significant contributions to social development. Positive impacts, innovations and benefits of internet on many aspects of daily life such as communication, exchange of information, journalism and media, promotion and advertisement, travel and holiday, public services, banking, trade, entertainment, social relations and intercultural interaction, environment, health and education are now acknowledged by everybody (Bayzan, 2011). Intense exchange of information, intense content production and possibility of both good and bad intentions in the production/sharing of information have led to the need of using internet in a conscious, reliable and effective manner. To this end, an internet user needs to act consciously against possible risks in an internet environment (Çubukçu \& Bayzan, 2013). In this scope, it is seen that competence areas such as command over technology, innovation, communication and cooperation, research and obtaining information, providing solutions for problems and "digital citizenship" have come to prominence for the students (ISTE, 2008). Being one of the competence areas concerning the youth, digital citizenship has become even more important in recent years. Ribble and Bailey (2005) defines digital citizenship as "teaching of appropriate technological behaviors". Also, digital citizenship is expressed as responsible behavior norms related to the use of technology. A person who knows how to correctly use technology and the digital tools coming into our lives together with technology, respects ethical rules and individual rights in digital platforms, as well, and uses digital tools safely and with a sense of responsibility is called "digital citizen" (Mossberger, Tolbert, \& McNeal, 2008).

With the decision numbered 184 and dated 2005, the Board of Education of Discipline decided to restructure Science High Schools, Anatolian High Schools, Anatolian Fine Arts High Schools, Sports High Schools, Anatolian Teacher Training High Schools, Anatolian Vocational and Technical High Schools, Technical High Schools, Religious High Schools and Anatolian Religious High Schools (Ünal \& Ünal, 2010). Similarly, it was stated in the Ninth Development Plan covering the years between 2007 and 2013 that the secondary education curricula would be based on program diversity instead of school diversity (Ninth Development Plan, 2006). Today this structure of secondary education continues. Ministry of National Education renewed the curricula of 21 secondary education courses in the 2017-2018 academic 
year and pusblished them on the website of the Board of Education and Discipline. In the renewed programs, it was emphasized that basic skills and competences, which are required and demanded for success of the students in daily life, were determined and comparisons were made with the programs of different countries and their experiences were considered (MEB, 2018). When the secondary education course schedules are examined, it is seen that students studying in different types of high schools have different compulsory and elective courses. The curricula renewed in 2018 were prepared in consideration of basic skills and competences. Among these basic skills and competences, information and communication technologies literacy, which reflects the features of the concept of digital citizenship, stands out. In this scope, the following were listed as the competences that students need to possess among the basic skills and competences of the curricula (MEB, 2018).

$\checkmark$ Information and communication technologies literacy is needed for keeping up with the age.

$\checkmark$ A student needs to have a positive attitude towards the use of information and communication technologies for satisfying the need of information and communication technologies literacy.

$\checkmark \quad$ A student should use information and communication technologies effectively.

$\checkmark$ A student should manage the flow of information from various sources.

$\checkmark$ A student should pay attention to the security warnings concerning access to and use of information.

$\checkmark$ A student should act in compliance with laws and moral rules.

$\checkmark \quad$ A student should have media literacy and digital literacy skills (MEB, 2018).

These skills and competences stated in the secondary education curricula renewed in 2018 are directly related to digital citizenship. It is striking that these skills and competences are related to the subdimensions of digital citizenship such as "digital skill”, "critical thinking", "digital security", "digital ethics" and "rights and responsibilities".

In Turkey, the frequency of internet usage is significantly higher among the young population aged between 16 and 24 than the other age groups (TÜIK, 2016). Therefore, high school students stand out as the group having the highest level of internet usage. Widespread use of digital technologies among the young is accompanied by certain opportunities as well as certain risks. For instance, abuse of personal information, exposure to inappropriate content or cyber 
bullying, insult, calumniation and use of private information or inappropriate images with the aim of inflicting damage etc. are commonly encountered. Individuals should be assisted in becoming digital citizens through the teaching of responsibility and ethics (Farmer, 2010). At this point, formal environments are of great importance in helping the youth to be digitally literate citizens in digital environments. Also, there are various environments where children can gain digital literacy skills apart from the formal education environment provided by the schools. In schools, course contents are determined by the curricula. In line with the principle that education prepares an individual to life, students should be raised in accordance with the requirements of the world in which students will take part as adults (Tüzel, 2013). In this scope, it is important that curricula include digital citizenship skills which are the main requirements of this century.

When considered in terms of digital citizenship, a course titled "Information and Communication Technologies" was delivered at the secondary education level until 2017. Examining the curricula of the course of Information and Communication Technologies (2017), Peker stated that aims of the course ( 3 aims), units of the course ( 2 units) and subjects of the course (12 subjects) included the elements of digital citizenship. However, in accordance with the secondary education course schedule published in 2018, this course was removed from the course schedule and was replaced by a course titled "Computer Science" which would be given to the students phase by phase and was designed in the form of two classes. Thus, considering that curricula and course structures were changed in 2018, determining the skills and competences that the students are required to acquire with respect to digital citizenship from all curricula renewed at the secondary education level and detecting the deficiencies in this area are important.

In the literature review, it is seen that studies concerning digital citizenship are quantitative survey research mainly directed at students and teachers (Altınay, 2016; Bardakc1, Akyüz, Samsa-Yetik, \& Keser, 2014; Çepni, Oğuz, \& Kılcan, 2014; Çiftçi \& Sakallı, 2016; Çubukçu \& Bayzan, 2013; Elçi \& Sar1, 2016; Kocadağ, 2012; Öztürk, 2015).There is only one domesitc study examining the curricula in terms of digital citizenship. Peker (2017) analyzed the curricula of the course of "information and communication technologies" in terms of the elements of digital citizenship. However, digital citizenship is not only related to information and communication technologies or computer science. Digital citizenship is an area which concerns all aspects of life and all courses. Therefore, analysis of the curricula of other courses 
at the secondary education level is important. Based on this thought, the present study aims at analyzing the secondary education curricula in terms of the subdimensions of digital citizenship.

\section{Method}

\section{Research Model}

The present study was carried out by using the qualitative research model. Qualitative research allows for the presentation of the research results on the basis of codes and categories through the reading of data one by one (Merriam, 1998).

\section{Data Sources of the Research}

In this study, curricula implemented at the secondary education level (High School 1st, 2nd, 3rd and 4th grades) in the 2017-2018 academic year were used as data source. In this scope, the curricula examined belong to the courses of Computer Science, English, Geography, Democracy and Human Rights, Religion and Ethics, Philosophy, French, Visual Arts, Music, Medical Information and Traffic, Revolution History and Atatürkism, History, Turkish Language and Literature and Contemporary Turkish and World History. These curricula are used in the Anatolian High Schools, Anatolian High Schools with Preparatory Class, Science High School, Social Sciences High School, Anatolian Religious High Schools, Science High Schools, Fine Arts High Schools, Sports High Schools and Anatolian Religious High Schools as per the decision numbered 56 and dated 19.02.2018 of the General Directorate for Secondary Education. When the secondary education course schedule is examined, the status of some courses as compulsory or elective (such as the course of computer science) changes depending on the type of the high school. Within the scope of the study, all secondary education courses included in the course schedule with compulsory and elective ones were analyzed. However, courses included in the Curricula of the Anatolian Religious High Schools such as Islamic law, hermeneutics, hadith and professional Arabic etc. were not included in the scope of the study and were not analyzed. 


\section{Collection and Analysis of Data}

Data were collected through document review. Document review encompasses the analysis of the written materials containing information on the phenomenon or phenomena to be examined (Yıldırım \& Şimşek, 2011).

In the analysis of the data, induction analysis method was used. Main aim of this analysis method is to reach concepts and relations which may explain the collected data. In the study, the steps stated below were taken by following the phases of coding data, determining the themes, organizingand identifying the data by codes and themes and interpreting the findings (Yıldırım \& Şimşek, 2011).

I. First, a form was designed to examine the content of the secondary education curricula related to digital citizenship. This form was based on "Digital Citizenship Scale for the Young" developed by Kuş, Güneş, Başarmak and Yakar (2017). This scale consist of eight subdimensions, which are communication, righs and responsibilities, critical thinking, participation, security, digital skills, ethics and commerce.

II. Secondly, curricula were analyzed on the basis of eight subdimensions of digital citizenship. All texts in the curricula were read by two researchers (excluding questions), and the statements determined were coded in the relevant value box. When content is related to two subdimensions, it was coded to both subdimensions separately. Sample data analysis performed in this process is shown in Table 1.

Table 1

Sample Data Analysis by Digital Citizenship Subjects of Secondary Education Curricula

\begin{tabular}{|c|c|c|}
\hline Codes & Subtheme & Theme \\
\hline $\begin{array}{l}\text { Making them individuals having a good understanding of } \\
\text { technological concepts, systems and processes as digital } \\
\text { citizens... } \\
\text { They benefit from information technologies in their } \\
\text { research and sudies related to music. }\end{array}$ & Digital Skill & \\
\hline $\begin{array}{l}\text { They take measures for ensuring protection of personal } \\
\text { data and information security in internet environment... } \\
\text { Necessary cautions should be made and necessary } \\
\text { measures should be taken for safe use of internet. }\end{array}$ & $\begin{array}{l}\text { Digital } \\
\text { Security }\end{array}$ & $\begin{array}{c}\text { Digital } \\
\text { Citizenship }\end{array}$ \\
\hline $\begin{array}{l}\text { Materials downloaded from internet and used should not } \\
\text { be plagiarised and ethical rules and coprights should be } \\
\text { respected. } \\
\text { While listening music in internet, ethical rules should be } \\
\text { paid attention. }\end{array}$ & Ethics & \\
\hline
\end{tabular}


III. Lastly, results of the analyses conducted by two researchers separately were compared and coding made by both researchers was marked as "Consensus" or "Dissensus". Agreement percentage formula was used with the aim of determining reliability in the content analysis. Agreement percentage was calculated as "Reliability = Consensus / (Consensus + Dissensus) x 100" (Miles and Huberman, 1994). According to Y1ldırım and Şimşek (2011), if agreement percentage is or exceeds $70 \%$ in reliability calculations, it is accepted that reliability percentage is reached. In the present study, agreement percentage of coding was found to be 0.81 for the first question by using this formula. In the incompatible codes, opinion of an expert was received and coding was repeated in the relevant value box. Categories were created under the eight subdimensions by combining these codes and findings were presented for each course curriculum. Texts of secondary education curricula were directly quoted during the presentation of the findings.

\section{Findings}

Findings of the study where secondary education curricula were analyzed in terms of subdimensions of digital citizenship are as follows. Availability of emphasis on digital citizenship in the curricula first in terms of subdimensions of digital citizenship and then in terms of the courses in the curricula is shown in the form of tables. Also, explanations were made by making direct quotations from the texts of secondary education curricula.

\section{Table 2}

\section{Availability of Subdimensions of Digital Citizenship in the Curricula}

\begin{tabular}{lll}
\hline Subdimensions & Course Name & $f$ \\
\hline & Computer Science & 23 \\
& English & 4 \\
& Music & 2 \\
\multirow{3}{*}{ Digital Skills (34) } & Medical Knowledge & 1 \\
& Revolution History and Atatürkism & 1 \\
& Turkish Culture and Civ. History & 1 \\
& Religion and Ethics & 1 \\
& Visual Arts & 1 \\
\hline
\end{tabular}




\begin{tabular}{lll}
\hline Subdimensions & Course Name & $f$ \\
\hline & Computer Science & 6 \\
& Music & 4 \\
Digital Security (15) & Visual Arts & 2 \\
& Turkish Language and Literature & 2 \\
& English & 1 \\
\hline & Music & 4 \\
& Democracy and Human Rights & 3 \\
Ethics (12) & Computer Science & 3 \\
& Revolution History and Atatürkism & 1 \\
& History & 1 \\
\hline \multirow{3}{*}{ Communication (9) } & Computer Science & 6 \\
& English & 2 \\
\hline \multirow{2}{*}{ Digital Participation (7) } & Turkish Language and Literature & Democracy and Human Righs \\
& Computer Science & 4 \\
\hline Rights and & Computer Science & 3 \\
Responsibilities(4) & Democracy and Human Rights & 2 \\
\hline \multirow{2}{*}{ Critical Thinking (2) } & Computer Science & 2 \\
\hline Digital Commerce (1) & Philosophy & 1 \\
\hline
\end{tabular}

As seen in Table 2, the course curriculum including the subdimensions of digital citizenship the most is the curriculum of the Computer Science course. In the Computer Science course, the subdimension included in the curriculum the most is "digital skills" while subdimensions of "rights and responsibilities" and "critical thinking" are included at the least. Subdimension of "digital commerce" is not included at all. Following the computer science course, curriculum of democracy and human rights course includes digital citizenship the most. The subdimension included in the curriculum of this course the most is "digital participation".

Curricula of English, music, visual arts, Turkish language and literature and revolution history and Atatürkism courses emphasize certain subdimensions of digital citizenship, as well. In the curricula of the courses of Turkish culture and civilisation history, geography, religion and ethics, philosophy and medical knowledge, there is only one reference to digital citizenship.

The subdimensions to which the curricula of these courses refer the most are "digital skills" and "digital security". On the other hand, the subdimensions referred in the curricula at the least are "critical thinking" and "digital commerce" and "rights/responsibilities". Subdimension of digital commerce is emphasized in the curricula only once and this stands out 
as a significant deficiency in terms of digital citizenship. Findings showing the secondary education courses highlighting digital citizenship and those having significant deficiencies in this issue are given in Table 3.

Table 3

Availability of Subdimensions of Digital Citizenship in Different Curricula

\begin{tabular}{|c|c|c|}
\hline Course Name & Subdimensions & $f$ \\
\hline \multirow{7}{*}{ Computer Science 44} & Digital Skills & 23 \\
\hline & Digital Security & 6 \\
\hline & Communication & 6 \\
\hline & Ethics & 3 \\
\hline & Rights and Responsibilities & 2 \\
\hline & Digital Participation & 3 \\
\hline & Critical Thinking & 1 \\
\hline \multirow{3}{*}{ Democracy and Human Rights (9) } & Digital Participation & 4 \\
\hline & Ethics & 3 \\
\hline & Rights and Responsibilities & 2 \\
\hline \multirow{2}{*}{ Visual Arts (3) } & Digital Security & 2 \\
\hline & Digital Skills & 1 \\
\hline \multirow{3}{*}{ Music 10} & Digital Security & 4 \\
\hline & Ethics & 4 \\
\hline & Digital Skills & 2 \\
\hline Medical Knowledge (1) & Digital Skills & 1 \\
\hline \multirow{2}{*}{ Revolution His. and Atatürkism (2) } & Digital Skills & 1 \\
\hline & Ethics & 1 \\
\hline History (1) & Ethics & 1 \\
\hline Turkish Culture and Civ. His. (1) & Digital Skills & 1 \\
\hline Geography (1) & Digital Security & 1 \\
\hline Religion and Ethics (1) & Digital Skills & 1 \\
\hline Philosophy (1) & Critical Thinking & 1 \\
\hline \multirow{2}{*}{ Turkish Language and Literature (3) } & Digital Security & 2 \\
\hline & Communication & 1 \\
\hline \multirow{3}{*}{ English (7) } & Digital Skills & 4 \\
\hline & Communication & 2 \\
\hline & Digital Security & 1 \\
\hline
\end{tabular}

When Table 3 is examined, it is seen that there is emphasis on the subdimensions of digital citizenship in 13 courses in the secondary education curricula and statements and explanations related to the subdimensions of digital citizenship are not available in the other nine courses. When the courses highlighting the subdimensions of digital citizenship are examined, it is seen that they are generally "verbal courses". Also, it is striking that there is no emphasis on digital citizenship in non-verbal courses such as physics, biology, chemistry and mathematics. 
In the curricula, references to digital citizenship exist under the title of "Competences" in the introduction part, which is common in all curricula. In the part titled "digital competence" under the title of competences, emphasis is laid on the security, critical thinking, digital skill and communication subdimensions of digital citizenship. This competence statement common in all curricula is as follows:

"It covers the use of information and communication technologies for business, daily life and communication in a safe and critical manner. This competence is supported by basic skills such as use of computers for access to information as well as evaluation, storage, production, presentation and exchange of information and participation in common networks and communication through internet."

\section{Computer Science}

Computer science curriculum consists of two parts as Level 1 and Level 2. When students take this course for the first time, they learn the attainments containing key issues related to computer science in the Level 1. When the course is taken for the second time, it is envisaged that students learn the attainments containing advanced level subjects in the Level 2. It has been determined that elements of digital citizenship are included in the general aims of the curriculum, skills specific to the courses and Level 1 attainments of the course. When the computer science course is evaluated in terms of digital citizenship, the following conclusions are reached:

\section{Digital Skills}

In the computer science curriculum, digital skills are included in different items in the part related to general aims. In the general aims, it is stated that the target is to raise individuals who understand technological concepts and systems, use information technologies in line with the purpose, can use internet-based services effectively, have acquired the problem solving skills, seek for opportunities for learning in the internet environment and can conduct works on web design.

As content, digital skills are included in the $3^{\text {rd }}$ unit titled "programming". In this unit, attainments are generally related to project development in online tools, cooperation and 
problem solving. Digital skills are given wide coverage in the part titled "skills specific to course". In this part, reaching different information in internet, evaluating social skills, effective use of technological tools and developing original products by using technological tools are emphasized.

\section{Digital Security}

In the part related to the general aims, with respect to digital security, it is stated that the target is to ensure protection of personal data in the internet environment and information security. In the part titled skills specific to the course, ability of the students to provide information security in the electronic tools is emphasized.

In the unit titled "Ethics, Security and Society", which is one of three units of computer science course, a separate title is opened for security and attainments related to digital security are included here. Under the title of security, attainments related to knowledge about information security and threats and safe identity management are included. The following attainments can be given as example for these references:

"Student explains the threats related to information security." (Level 1; Unit 1; Subject 2)

"Student carries out the processes for providing information security in the personal computer and network environment." (Level 1; Unit 1; Subject 2)

\section{Communication}

Communication dimension of digital citizenship is referred to in the part dedicated to skills specific to the course. With respect to communication, it is emphasized that these skills will allow for correct and effective use of Turkish, improved listening and speaking skills of students in audiovisual tools, communication with different students and intercultural interactions by increasing communication skills through the use of different communication technologies. 


\section{Ethics}

The first subject title of the computer science course curriculum is "ethical values". In the attainments under this title, ethical dimension of digital citizenship is given wide coverage. At this point, it is emphasized that ethical values and code of ethics are applicable in the internet environment, programs and communications in the virtual platforms. In the part related to the aims specific to the course, awareness about compliance with online reputation management and intellectual property rights is emphasized. The following attainments can be given as example for digital ethics:

"Student explains the ethical principles that should be respected during the use and management of information technologies and internet environment." (Level 1; Unit 1; Subject 1)

"Student gives examples for cases of breach of ethical principles." (Level 1; Unit 1; Subject 1)

\section{Rights and Responsibilities}

There is reference to the "rights and responsibilities" dimension of digital citizenship only in the part titled "skills specific to the course". In this part, it is emphasized that the students will know their rights and responsibilities in the online environments and display positive, safe, legal and ethical behaviors in the use of technologies. In the attainments part of the curriculum, there is no reference to the "rights and responsibilities" dimension of digital citizenship.

\section{Digital Participation}

"Digital participation" dimension of digital citizenship is included in the parts related to general aims, skills specific to the course and attainments in the computer science curriculum. In this respect, development of innovative and creative projects for the solution of problems experienced by the old or the disabled in daily life and new ideas for real world problems is emphasized. 


\section{Critical Thinking}

There is only one emphasis on the "critical thinking" subdimension of digital citizenship iin the part titled "skills specific to the course". Under the title of "restructuring information" in the part related to the skills specific to the course that the computer science course curriculum targets to make students adopt, it is emphasized that students should evaluate the accuracy, reliability and suitability of the information, media, data or other sources they reach. The part on attainments does not have a reference to "critical thinking", which is another important subdimension of digital citizenship.

\section{Democracy and Human Rights}

Democracy and human rights curriculum includes the concepts of digital citizen, digital citizenship and cyber bullying. As skill, the skill of "using information and communication technologies" is mentioned. Also, references are made to "ethics", "digital participation" and "rights and responsibilities" subdimensions of digital citizenship in the curriculum of the democracy and human rights course.

\section{Ethics}

In the curriculum of democracy and human rights course, basic principles are specified in the part titled "learning-teaching process". One of these principles is "effective use of information and communication technologies in line with ethical principles", which is specified in the ninth article. In the explanations made under this article, use of information and communication technologies in line with ethical principles, active participation in democratic and social life and observance of ethical principles in this process (compliance wiith public decency, not misleading others, not taking actions considered crime by laws etc.) are emphasized.

\section{Digital Participation}

In the last attainment explanation of the theme titled "Living the democracy: active citizenship" in the curriculum of democracy and human rights course, participation in democratic life through social media tools is emphasized. 


\section{Rights and Responsibilities}

In the last attainment of the theme titled "Living the democracy: active citizenship", it is stated with respect to the subdimension of rights and responsibilities that students should use information and communication technologies in a responsible manner without misleading or causing damage to other people and should not engage in actions considered crime by laws.

\section{Visual Arts}

Curriculum of the visual arts course gives coverage to the digital security and digital skills subdimensions of digital citizenship.

\section{Digital Security}

In the part titled "points to consider" in the curriculum of the visual arts course, warnings related to the safe use of internet and information technologies are given. Concept of "cyber security" is used, and it is emphasized that security principles should be explained to the students during the lectures.

\section{Digital Skills}

In the area titled "Cultural Heritage" of the visual arts course curriculum, there is an attainment related to the preparation of a webpage and promotion presentations on the museums and art galleries. The following is emphasized in the explanation of this attainment:

"Students are made to create and present webpages, brochures, school newspapers, posters or promotion presentations for museums and art galleries by making use of the information they obtained..." (12th Grade; 2nd Learning Area).

\section{Music}

Out of subdimensions of digital citizenship, "digital security", "ethics", “digital skills" stand out in the music course curriculum. There is no statement related to the other subdimensions in this curriculum. 


\section{Digital Security}

In the part related to the learning areas, attainments and explanations at the level of $9,10,11$ and $12^{\text {th }}$ Grades of the curriculum, the necessity of paying attention to "cyber security" while listening to music in the internet environment is emphasized separately for each grade. The following attainment statement can be given as example from the relevant curriculum:

"It is reminded that cyber security and ethical rules should be respected while listening to music in the internet environment." (9th Grade, 3rd Learning Area, 2nd Explanation)

\section{Digital Skill}

In an attainment specified in the learning area titled "musical creativity" applicable to all class levels in the music course curriculum, use of information technologies in the research and studies related to music is emphasized. Also, in the explanation of an attainment for the $12^{\text {th }}$ grade students, it is emphasized that students should create a music archive as digital data by making use of the information technologies. The following examples can be given for the references in the curriculum:

"Student benefits from information technologies iin the research and studies related to music." (Grade 11, Learning Area 3, Attainment 3)

"Students create a music archive as both written and digital data with the support of various information technology tools (computer, various memory units etc.)." (Grade 12, Learning Area 4, Attainment 3).

\section{Ethics}

In the part related to learning areas, attainments and explanations applicable to all grades in the curriculum of the music course, the necessity of abiding by the ethical rules while listening to music in the internet environment is repeated in all classes. 
"Students are reminded that cyber security and ethical rules should be observed while listening to music in the internet environment." (Grade 10, Learning Area 3 and Attainment 2).

\section{Medical Knowledge}

In the part titled "points to consider" of the curriculum of the medical knowledge course, there is only one explanation concerning the subdimension of digital skill of digital citizenship. In this explanation, it is emphasized that students should use information technologies actively and visit official webpages. Other than this, there is no reference to digital citizenship in the curriculum of medical knowledge course.

\section{Revolution History and Atatürkism}

In the curriculum of Revolution History and Atatürkism course, subdimensions of digital citizenship are emphasized only in the part of points to consider in the implementation of the curriculum. In this part, there are references to the subdimensions of digital skill and ethics. In the curriculum, use of sources such as internet in practices including historical research method is emphasized. Also, in the part related to the points to consider in the implementation of the curriculum, avoidance of plagiarism and observance of ethical rules and copyrights in the use of materials downloaded from internet are expressed as follows:

Rules determined by the Ministry of National Education should be respected in the use of digital sources. In particular, sources should be properly cited in the use of materials downloaded from internet to avoid plagiarism and ethical rules and copyrights should be observed (points to consider in the implementation of the curriculum).

\section{History}

As in the course of Revolution History and Atatürkism, ethics subdimension of digital citizenship is emphasized in the curriculum of the history course. With respect to this, it is stated that sources downloaded from internet should be cited properly to avoid plagiarism and ethical rules and copyrights should be respected in the part titled points to consider in the implementation of the curriculum. 


\section{Turkish Culture and Civilisation History}

In the curriculum of the Turkish culture and civilisation history course, there is reference only to the digital skill subdimension of digital citizenship. In this reference, it is stated that students should be directed to the digital sources in the part related to the points to consider in the implementation of the curriculum. Other than this, there is not any attainment statement or reference to digital citizenship.

\section{Geography}

Unlike the curricula of other courses, geography course curriculum makes reference to digital commerce subdimension of digital citizenship. In the unit titled "human systems" of the curriculum for the $12^{\text {th }}$ grade geography course, there is an attainment stating that the importance of cyber security in e-commerce should be emphasized. This statement is as follows:

"Importance of cyber security in e-commerce is emphasized by including commerce practices." (Grade 12, Learning Area 2, Attainment Explanation 11).

\section{Religion and Ethics}

In the curriculum of the religion and ethics course, there is reference only to digital skill subdimension of digital citizenship. In the part related to the attainments, it is recommended that contemporary information sources should be used. The relevant statement in the curriculum is as follows:

"It is emphasized that dreams, revelation and inspiration are not accepted as information sources by Islamic scholars. Also, contemporary information sources (like digital records) are mentioned. (Grade 9, Unit 1, Attainment Explanation 1)

\section{Philosophy}

In the curriculum of the philosophy course, there is reference only to the critical thinking subdimension of digital citizenship. Other than this, there is no emphasis on digital citizenship 
in the attainment statements or explanations. It is stated that students should discuss the information shared in internet and social media in terms of value and reliability of the information.

"It is ensured that students discuss the information shared in newspaper and magazine news, internet, social media and TV programs in terms of value and reliability of the information." (Grade 10, Unit 3, Attainment Explanation 2)

\section{Turkish Language and Literature}

In the curriculum of the Turkish language and literature course, there are references to the digital security and communication subdimensions of digital citizenship. With respect to the subdimension of digital security, it is stated in the part related to the points to consider in the implementation of the curriculum that rules related to the use of digital sources and security measures should be respected. In the part of contents, it is stated that personal information should be secured while writing e-mails. Also, there is reference to the communication subdimension of digital citizenship in the part of contents and it is stated that "students should carry out e-mail writing studies in accordance with the phases of letter writing".

\section{English}

There are references to the subdimensions of digital security, communication and security of digital citizenship in the curriculum of the English course.

\section{Digital Skills}

In the part related to the attainments of the curriculum of the English course, it is emphasized that students should be able to write online/digital stories in cooperation, to analyse different professions through websites and to identify the jargon related to technology and web. Also, it is stated that students should be able to write an e-mail to a hotel or a friend. It is emphasized that they should visit websites and learn more information about the companies. These references are made in the curriculum as follows:

"Students will be able to write an online/digital story in cooperation." (Grade 10, Theme 8, Subtheme of writing, Attainment 2) 
"Students will analyse different job advertisements from newspapers/websites to match with the CVs." (Grade 11, Theme 1, Subtheme of Reading, Attainment 1)

"Students will be able to identify a jargon related to a webpage or a written word." (Grade 12, Theme 9, Subtheme of Reading, Attainment 1)

\section{Discussion and Conclusion}

The following conclusions were reached in the present study where secondary education currciula were analysed in terms of the subdimensions of digital citizenship.

At the level of secondary education, the highest number of references to digital citizenship was found in the computer science course curriculum. This curriculum gives wide coverage to digital skills such as understanding technological concepts, using technological systems and processes, using information technologies effectively and solving a problem encountered. This finding is quite normal. However, coverage of rights and responsibilities in digital platforms as well as ethics and critical thinking skills is highly limited and this is a signigicant problem. It is highly important that individuals use their digital skills in line with rights and responsibilities and ethical principles. Also, individuals should have the capacity to make an assessment on the validity and reliability of the information that they want to reach since the information provided in digital platforms might be wrong, incorrect or deficient. In this sense, individuals should be able to think critically. However, it is seen that curriculum of the course of computer science scarcely addresses this skill. When considered in connection with computer literacy, course of computer science plays a key role in helping students acquire certain skills. In this scope, students taking this course should have the skills to determine the social, economic and ethical results and to use computer effectively in daily life, which are the most important skills following knowledge about software and hardware (Korkmaz \& Mahiroğlu, 2009). Peker (2017) analysed the curriculum of the information and communication technologies course in terms of the elements of digital citizenship and concluded that this course included the elements of digital citizenship in a highly limited manner. Öztürk (2015, p.95) concluded that "digital citizenship should be taught with sample activities in a more effective and practical manner in the courses of computer technologies and citizenship and democracy education in the schools to raise a good citizen and a good digital citizen". In all stages of education, education system should take digital learning environments into 
consideration in order to promote learning and personal development and global citizenship skills and values should be incorporated into the system (Granberg, 2009; Seale, Draffan, \& Wald, 2010: cited by Altınay, 2016).

Technology has had a significant impact on citizenship education as well as all other areas. Although difficulty of using internet in a controlled manner makes it hard to take conscious steps with respect to the impact of technology on social change, many young citizens living in the contemporary world are interested in contributing to the society (Ribble, Bailey, \& Ross, 2004). In this respect, it is important to determine how the young citizens are affected by technology and how the curricula direct them during citizenship education. The findings of this study show that course of "democracy and human rights" follows computer science course in terms of coverage of digital citizenship in the curriculum. The curriculum of this course states that students should participate in democratic life from digital platforms in an effective manner by using information and communication technologies in accordance with ethical principles but this reference is highly insufficient. Also, coverage of rights and responsibilities in the digital environment is very limited. However, as stated by Çubukçu and Bayzan (2013), all individuals, as digital citizens, have responsibilities against the injustice and illegal contents available in the internet environment. Thus, rights and responsibilities against all risk groups in the internet cannot be ignored.

"Democracy and human rights" course is of great importance for teaching the students at the secondary education level their rights and responsibilities. However, a serious paradox shows up at this point. While instructors still focus on traditional citizenship education, the young and even children are taking part in the "digital environments" much more and going beyond the borders of the current citizenship education. In this sense, the young have put the interactive information technologies at the center of social life (Bennett, 2008). This paradox has created significant gaps between the "citizenship rights and responsibilities taught in te school" and "rights and responsibilities in the digital environments" in which the young frequently take part. Turkey is at the top in terms of the number of internet users (Bayzan \& Özbilen, 2011). Also, when statistics are examined, it is seen that the frequency of internet usage is quite high especially among the young population when compared to the other age groups (TÜİ, 2017). Additionally, nation-wide information projects such as e-state and FATIH (Movement of Enhancing Opportunities and Improving Technology) Project in Education are considerably important developments to ensure that Turkey uses technology in an effective and correct 
manner in the digitalising world (Çubukcu \& Bayzan, 2013). However, it is thought-provoking that subdimensions of digital citizenship are not addressed sufficiently in the course of "democracy and human rights", which might teach students at the secondary education level their rights and responsibilities in the digital environments.

Digital citizenship is not only related to the course of computer science and democracy and human rights. Digital citizenship and its subdimensions are closely associated with the other courses, as well. Thus, curricula of the other courses include references to digital citizenship and its subdimensions. For instance, references to digital security, ethics and digital skills are encountered in the music course curriculum. It is stated that cyber security and ethical rules should be respected in particular while listening to music in the internet environment. In internet environment, security is explained as all kinds of unauthorized access to the defined information including reading, learning, modifying or deleting (Tennant, Ober, Lipow, Lynch, \& Tonta, 1996). Mason (1986) determined ethical problems of the information age under four main titles, which are copyright, accuracy, confidentiality and access. Considering this comprehensive definition and types of digital security and ethics, it is striking that secondary education curricula are insufficient in this regard. Subjects of digital security and ethics, which are found to be deficient in the secondary education curricula, are actually related to the concept of "information ethics". Information ethics does not concern only those working in the information sector or institutions and organisations providing services in this field, and its boundaries cannot be drawn clearly. It is of particular concern to all individuals and institutions directly or indirectly associated with science and technology (Fidan, 2016).

In the curriculum of the English course, digital citizenship is emphasized with respect to the use of English in the internet environment (digital skills) and communication in English.

References to digital citizenship are highly limited (only once or twice) in the curricula of the courses of medical knowledge, revolution history and Atatürkism, history, Turkish culture and civilisation history, geography, religion and ethics and philosophy. In these courses, references are related to the use of digital sources and compliance with ethical principles.

Considering the duration of internet usage by the students at the secondary education level, it is important to design the curricula in a manner to raise awareness among the students, families and schools for the use of internet for beneficial purposes (Kahraman, Yalçın, \& Çevik, 2011). 
At the secondary education level, subdimensions of digital citizenship covered by the curricula most frequently are digital skills and digital security while the subdimensions included in the curricula at the least are critical thinking, digital commerce and rights/responsibilities. Nevertheless, as stated by Hollandsworth, Dowdy and Donovan (2011), the concept of digital citizenship covers a wide spectrum of behaviors having various risks and probable negative outcomes.

\section{Recommendations}

Within the scope of this study, secondary education curricula were assessed in terms of the subdimensions of digital citizenship and courses were compared. Inclusion of digital citizenship and its subdimensions in the curricula of the courses at the secondary education level can be considered to be a positive result. However, considering that digital environments are various, digital sources are abundant and rates of the young to be present in the digital environment are high in today's world, it can be recommended that courses give wider coverage to the skills required by digital citizenship. When the digital skills envisaged by the curricula are taken into account, subdimensions of digital citizenship can be associated with the relevant subjects in all courses at the secondary education level. With a broad perspective, digital citizenship and its subdimensions should not be associated only with computer science course and the curricula of the other courses should include the information and skills required by digital citizenship. Also, course of democracy and human rights should give wider coverage to the teaching of rights and responsibilities in the digital environment. In our country, if the young, who have high rates of computer and internet usage, know how to use information and communication technology tools and internet correctly, many problems in daily life can be eliminated. 


\section{References}

Altınay, G.Z. (2016). Tüm eğitim kademesinin geleceği için dijital vatandaşlığın içselleştirilmesi. Ĕgitim ve Bilim, 41(186), 37-148.

Bardakcı, S., Akyüz, H.İ., Samsa-Yetik, S., \& Keser, H. (2014). Öğretmen adaylarının dijital vatandaşlık eğilimleri üzerine sosyokültürel bir inceleme. 8th International Computer \& Instructional Technologies Symposium (ICITS). Trakya Üniversitesi, Edirne.

Bayzan, Ş., \& Özbilen, A. (2011). Dünyada internetin güvenli kullanımına yönelik uygulama örnekleri ve türkiye'de bilinçlendirme faaliyetlerinin incelenmesi ve Türkiye için öneriler. 5th International Computer \& Instructional Technologies Symposium, 22-24 Eylül, Fırat Üniversitesi, Elazı̆̆.

Bennett, W.L. (2008). Changing citizenship in the digital age. Civic life online: Learning how digital media can engage youth. W. Lance Bennett, The John D. \& Catherine T. MacArthur, (Eds). Foundation Series on Digital Media and Learning. Cambridge, MA: The MIT Press, 1-24. doi: 10.1162/dmal.9780262524827.001.

Çepni, O., Oğuz, S., \& Kılcan, B. (2014). İlköğretim öğrencilerinin dijital vatandaşlığa yönelik görüşleri. Türkiye Sosyal Araştırmalar Dergisi, 18(3), 251-266.

Çiftçi, S., \& Sakallı, H. (2016). Sınıf öğretmeni adaylarının dijital vatandaşlık düzeyleri ile siber zorbalık eğilimleri arasındaki ilişkinin incelenmesi. Ĕ̈itim Teknolojisi Kuram ve Uygulama, 6(2), 100-119. DOI: 10.17943/etku.97311.

Çubukçu, A., \& Bayzan, Ş. (2013). Türkiye'de dijital vatandaşlık algısı ve bu algıyı internetin bilinçli, güvenli ve etkin kullanımı ile artırma yöntemleri. Middle Eastern \& African Journal of Educational research, 5, 148-174.

Dokuzuncu Kalkınma Planı, (2006). Dokuzuncu kalkınma planı. Retriewed 16, April, 2018, from http://www.kalkinma.gov.tr/Lists/Kalknma\%20Planlar/Attachments/1/plan9.pdf.

Elçi, A.C., \& Sarı, M. (2016). Bilişim teknolojileri ve yazılım dersi öğretim programına yönelik öğrenci görüşlerinin dijital vatandaşl1k bağlamında incelenmesi. Çukurova Üniversitesi Sosyal Bilimler Enstitüsü Dergisi, 25(3), 87-102.

Farmer, L. (2010) 21. Century standarts for information literacy. Leadership, 39(4), 20-22. 
Fidan, M. (2016). Bilişim etiği boyutlarına göre bilişim teknolojileri ve yazılım dersi öğretim programı kazanımlarının incelenmesi. Kastamonu Eğitim Dergisi, 24(4), 1641-1654.

Hollandsworth, R., Dowdy, L., \& Donovan, J. (2011). Digital citizenship in K-12: It takes a village. TechTrends, 55(4), 37-47.

ISTE. (2008). National education technology standarts for students. Retriewed 17, April, 2018, from https://www.iste.org/docs/pdfs/20-14_ISTE_Standards-S_PDF.pdf.

Kahraman, S., Yalçın, S.A., \& Çevik, C. (2011). Lise öğrencilerinin internet kullanımı. 5. International Computer and Instructional Technologies Symposium, 22-24 Eylül, Fırat Üniversitesi, Elazığ.

Kocadağ, T. (2012). Öğretmen adaylarının dijital vatandaşlık düzeylerinin belirlenmesi. Yayımlanmamış Yüksek Lisans Tezi. Karadeniz Teknik Üniversitesi Eğitim Bilimleri Enstitüsü, Trabzon.

Korkmaz, Ö., \& Mahiroğlu, A. (2009). Üniversiteyi yeni kazanmış öğrencilerin bilgisayar okuryazarlık düzeyleri. Kastamonu Ĕ̈itim Dergisi, 17(3), 983-1000.

Kuş, Z., Güneş, E., Başarmak, U., \& Yakar, H. (2017). Gençlere yönelik dijital vatandaşlık ölçeğinin geliştirilmesi: geçerlik ve güvenirlik çalışması. Journal of Computer and Education Research, 5(10), 298-316. https://doi.org/10.18009/jcer.335806.

Mason, R.O. (1986). Four ethical issues of information age. MIS Quarterly, 10 (1).

MEB, (2018). Sikça sorulan sorular. Retriewed 16, April, 2018, from http://mufredat.meb.gov.tr/SSS.aspx.

Merriam, S. (1998). Qualitative research and case study applications in education. Revised and expanded from case study research in education. USA: JB Printing.

Miles, M.B., \& Huberman, A.M. (1994). Qualitative data analysis: An expanded Sourcebook. $\left(2^{\text {nd }}\right.$ ed). Thousand Oaks, CA: Sage.

Mossberger, K., Tolbert, C.J., \& McNeal, R.S. (2008). Digital citizenship. Cambridge, MA: MIT Press.

Öztürk, M. (2015). Ortaokul öğrencilerinin dijital vatandaşlık düzeyleri. Yayımlanmamış Yüksek Lisans tezi. Kastamonu Üniversitesi Sosyal Bilimler Enstitüsü, Kastamonu. 
Peker, Ü.D. (2017). Bir öğretim programındaki dijital vatandaşlık öğeleri ve ortaöğretim öğrencilerinin dijital vatandaşlık ögelerine sahip olma durumları. Karaelmas Journal of Educational Sciences, 5, 180-195.

Ribble, M. S., Bailey, G. D., \& Ross, T. W. (2004). Digital citizenship: Addressing appropriate technology behavior. Learning \& Leading with Technology, 32(1), 6.

Riblle, M., \& Bailey, G. (2005). Teaching digital citizenship: when will it become a priority for 21st century schools?, Retriewed 17, April, 2018, from http://www.digitalcitizenship.net/uploads/TeachingDC10.pdf adresinden.

Tennant, R., Ober, J., Lipow, A.G., Lynch, C.A., \& Tonta, Y. (1996). Internet el kitabı. (2 ${ }^{\text {nd }}$ ed.) Ankara: Türk Kütüphaneciler Derneği.

TÜİK, (2017). Hane halkı bilişim teknolojileri kullanım araştırması, Retriewed 02, December, 2018, from http://www.tuik.gov.tr/HbPrint.do?id=24862.

Tüzel, S. (2013). Okul ile öğrenci yaşamı arasındaki duvarları yıkmak: popüler medyayı sınıfa taşımak. I. Türkiye Çocuk ve Medya Kongresi. Bildiriler Kitabı cilt 1.

Ünal, F., \& Ünal, M. (2010). Türkiye'de ortaöğretim programlarının gelişimi. Sosyal Bilimler Araştırmaları Dergisi, 1, 110-125.

Yıldırım, A., \& Şimşek, H. (2011). Sosyal bilimlerde nitel araştırma yöntemleri. (8. baskı). Ankara: Seçkin Yayıncılık. 